Research Article

\title{
Docking Studies on Ache and Tau Proteins with Marine Bioactive Compound Squalene, A New Approach to Design Anti-Alzheimer's Drug Targets
}

\author{
Kukkarasapalli Praveen, Kuna Yellamma* \\ Department of Zoology, Sri Venkateswara University, Tirupati, Andhra Pradesh, India. \\ *Corresponding author's E-mail: yellamma55@gmail.com
}

Received: 24-07-2021; Revised: 18-09-2021; Accepted: 26-09-2021; Published on: 15-10-2021. \begin{abstract}
Natural bioactive compounds of Marine origin have attracted the attention of many biologists and chemists in the world over for the last five decades because it has proven to be a rich source of structurally diverse and complex compounds exhibiting numerous interesting biological functions. At present, many research findings have provided insight into biological activities of marine natural compounds such as antioxidant- and anti-cholinesterase activity and neuroprotective effects on neurodegenerative diseases, viz. Alzheimer's and Parkinson's. The main pathological hallmarks of AD is the formation senile plaques, neurofibrillary tangles and the most incredible physiological and biochemical changes are reduction in acetylcholine (ACh) levels in the hippocampus and cortex of the brain and loss of memory, decaying language etc. Present study is focused on to enhance the acetylcholine levels and subsequently to prevent the formation of Senile Plaques and Neuro Fibrillary Tangles in tau protein responsible for Alzheimer's disease by using natural bioactive compound Squalene. Computational Biology and Bio-informatics have the potential not only to speed up the drug discovery process but reduces the costs. Further, they also change the way drugs are designed by using Docking Techniques employed to dock a set of marine bioactive compounds within the active site region of $1 \mathrm{~B} 41$ \& $2 \mathrm{~V} 17$ by using Auto Dock vina. The docking simulation clearly predicted the interaction and highest binding energy docking scores against Squalene, analogues were retrieved from ZINC database i.e. ZINC 0118 (-8.9) and ZINC $0142(-8.3)$ for 1B41 \& 2 V17 enzymes respectively. Further, we Studied visualization aspects in PyMol and also satisfied the biological activity predictions like OSIRIS, Molinspiration and PASS Prediction results by inhibiting the activity of Tau and Acetyl Cholinesterase receptors in AD.
\end{abstract}

Keywords: Alzheimers Disease (AD), Marine bioactive compound Squalene, Acetylcholinesterase (AChE) and Tau proteins.

QUICK RESPONSE CODE $\rightarrow$

DOI:

10.47583/ijpsrr.2021.v70i02.031

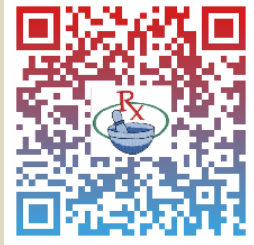

DOI link: http://dx.doi.org/10.47583/ijpsrr.2021.v70i02.031

\section{INTRODUCTION}

A

Izheimers Disease, the most scattered neurodegenerative disease causes a progressive destruction in serviceable performances and continuous reduction in cognitive activities and memory ${ }^{1-}$ ${ }^{6}$ in aged people. It is a multifactorial illness, mainly related to oxidative stress leading to the inequity between production and detoxification of Reactive Oxygen Species (ROS), a chief issue for developments of neurodegenerative diseases ${ }^{7}$. It is estimated that people suffering with $A D$ is about $10 \%$ between $65-70$ years and $50 \%$ in people above 85 years of age and this number is going to double by 2030 .

The two major pathological hallmarks of $A D$ are the one i.e. Acetyl Choline (ACh), the principal neurotransmitter in the brain responsible for cholinergic transmission and the enzyme Acetyl Cholinesterase (AChE) deposited within the Neuro Fibrillary Tangles and amyloid plaques associated with $A D^{8}$ and plays a key role in hydrolysis of the neurotransmitter Acetyl Choline. Recent research findings provide substantial evidence that Acetyl Cholinesterase (AChE) inhibitors of marine natural bioactive compounds may restrain the biological activity of $\mathrm{AChE}$ and hence swell the acetylcholine level in the brain. Structure of the complex of antibody MN423 with a fragment of tau protein interacts with different components of the plaques producing amyloid system, participate in phosphorylation of the microtubule binding protein tau that contributes to the formation of Neuro Fibrillary Tangles and Plaques. Thus, development of tau inhibitors draws wide attention of the scientific community for reducing tau phosphorylation and the debilitating effects of Alzheimers Disease. ${ }^{9}$ The marine drugs will hold back the biological activity of Tau like neuroprotective effects, cutback in tau hyper phosphorylation and turn down $\beta$-amyloid production etc.

Oceans account for $71 \%$ of the earth's surface and are the largest remaining reservoirs of bioactive compounds ${ }^{10]}$. For centuries, the medicinal properties of macro algae were limited to traditional and folk medicines ${ }^{11]}$. However, in recent years, industries have been focusing their attention on the discovery and development of compounds from marine algae ${ }^{12}$. Many species of marine algae have long been used in food diets as well as traditional remedies in Eastern countries. Accordingly, oceanic algae contain enormous prospective to be used in neuroprotection ${ }^{13}$. Consequently through the past decade, 
the Neuro protective properties of diverse compounds from Squalene have been investigated in neurodegenerative diseases, such as Alzheimer's (AD) and Parkinson's (PD) ${ }^{14]}$. Marine compounds are currently being explored as novel and sustainable sources of bioactive compounds for both pharmaceutical and neutraceutical application. Now-a-days, Insilco molecular docking approaches are routinely used in modern drug design to understand drug-receptor interaction. The most recent phase in the new drug discovery process is utilizing the knowledge of the three dimensional structures of target macromolecules.

At present, several drugs are available in market for treating $A D$ but they exert, rather more side effects than give relief. Hence, one of the most thrust areas in current medicinal chemistry researches is to identify the safe and effective natural bioactive compound marine origin for treatment of a number of neurological diseases ${ }^{15]}$. Hence, the present research is focussed mainly on a new approach to design anti-Alzheimer's Agents with selected Bioactive Compound Squalene from marine source through docking studies on AChE and Tau proteins, the two major proteins responsible in manifestation of Alzheimer's disease.

\section{MATERIALS AND METHODS}

\section{Software's required:}

\section{PDB ID 1B41}

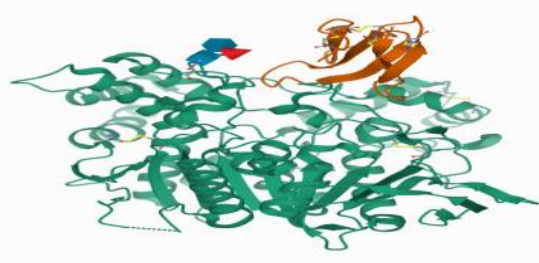

\section{Collection and preparation of Ligands}

Marine natural bioactive compound Squalene analogues against AChE and TAU proteins inhibitors were selected based on literature ${ }^{22}$. Total 200 analogues were collected from Zinc Database for marine bioactive compound Squalene, by using key word search. Then all these analogues were added with hydrogens, energy minimized with UFF force field using conjugate-gradient algorithm by Pyrex Virtual Screening tool, subjected to against 1B41 and 2V17 proteins. Among these 200 ligands, only 8 compounds i.e. ZINC ID 0118, ZINC ID 0040, ZINC ID 0026, ZINC ID 0025, ZINC ID 0016, ZINC ID 0115, ZINC ID 0139, ZINC ID 0052 and ZINC ID 0142, ZINC ID 0016, ZINC ID 0026, ZINC ID 0040, ZINC ID 0014, ZINC ID 0070, ZINC ID 0139 and ZINC ID 0145 showed high binding affinity and best docking score against 1B41and 2V17 Proteins respectively.

\section{Docking Method}

Both ligand-based and structure-based virtual screening methods have their advantages and drawbacks. Docking
In this study, we employed various tools and software's to analyse the proteins Human Acetylcholine Esterase (AChE) and Structure of the complex of antibody MN423 with a fragment of tau protein retrieved from Protein Data Bank (www.pdb.org/pdb/) [16]. The drug molecules were downloaded from PubChem database ${ }^{[17]}$ Analysis of protein and ligand hydrogen bonding interaction and visualization aspects were carried out by using PyMol tool [18], protein energy minimization by using Argus Lab tool [19], molecular docking studies by using Auto Dock Vina ${ }^{[20]}$, protein pocket binding sites predicted by CASTp program (http://cast.engr.uic.edu)[21] and finally ADME properties finished by using OSIRIS, Molinspiration and PASS prediction tools etc.

\section{Preparation of protein structure}

The crystal structures of (PDB ID: 1B41) and Structure of the complex of antibody MN423 with a fragment of tau protein (PDB ID: 2V17), retrieved from Protein Data Bank (PDB) have the pharmacological targets for development of new drugs to treat $A D$. We removed all the hetero atoms of both receptors such as water molecules, bound ligands and any other co-crystallized solvents from the PDB files. Then, the polar hydrogens were added and partial charges were assigned by using an Argus Lab force field.

\section{PDB ID 2V17}

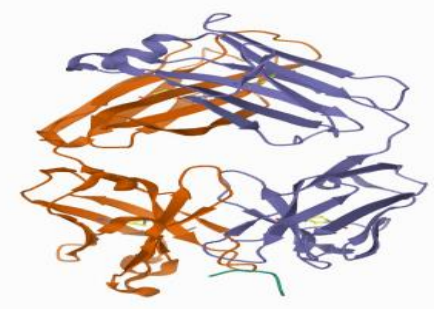

calculations were carried out by using Docking Server ${ }^{\text {[23- }}$ 24]. Partial charges were added to the ligand atoms. However, since the docking methods are able to select more diverse actives than ligand-based methods like 2D similarity or substructure searching ${ }^{[25]}$ we have used Pyrex Virtual screening method. The simulation study docking score is the binding energy and the best docking mode is the highest scoring pose or the conformation with the lowest binding energy.

\section{Enerzyminimization through Argus Lab}

In Molecular docking studies [26] of all proposed ligands were constructed in Argus Lab workspace and all ligands were energy minimized by AM1 as semiemperical method. The geometry optimization of AChE and Tau enzymes were performed by using Universal Force Field (UFF) as a molecular mechanic method. The docking process was made for all ligands with related groups of each ligand against their proteins through Pyrex virtual screening tool. The binding location of receptors having the best pose and conformation for all ligands. 


\section{RESULTS AND DISCUSSION}

\section{Analysis of Binding site through CASTp server}

Binding and catalytic active sites of (AChE and Tau) proteins are often associated with structural pockets and cavities. These catalytic residues were further examined with Compound Atlas of Surface Topography of proteins (CASTp) server. It afford with identification of dimension surface accessible pockets as well as interior remote cavities of receptors. It processes the experimental evidence on AChE and Tau enzymes showed the presence of amino acid residues at pocket binding sites. Based on this interaction studies, it might be possible to inhibit the enzymes activity and thus useful to put-off Alzheimers Disease. The following residues were present in the pocket binding site Present in protein 1B41:Tyr-124, Tyr-337, Tyr133, Pro-498, Gln-174, Gln-413, Asn-233,Gln-413,Asn233,Gly-234,Gly-234,Asn-233,Asn-233,Tyr-72,Tyr-133, Tyr133,Tyr-337, Thr-238, Thr-238, Pro-232, Glu-313,Trp-532, Arg-475 \& Leu-518 etc. and it was obvious that the following residues were present in the pocket binding site present in protein 2V17: Gln-557, Ser-559, ser-65, Ser-63, Phe-474, Leu-495, Ser-507, Asp-139, Gly-136,Cys-137, Leu495, Gln-557, Phe-474 etc.

Based on above pocket binding sites of protein, it was evident that these drug molecules were able to tightly coil and bind to any one of the sub sites of selected target proteins and thus inhibits AChE and tau protein activity.

\section{PDB ID 1B41}

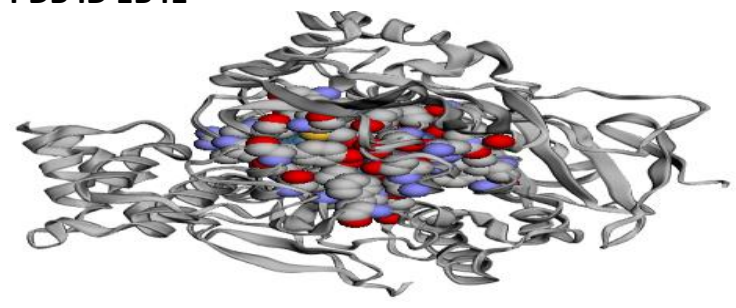

\section{PDB ID 2V17}

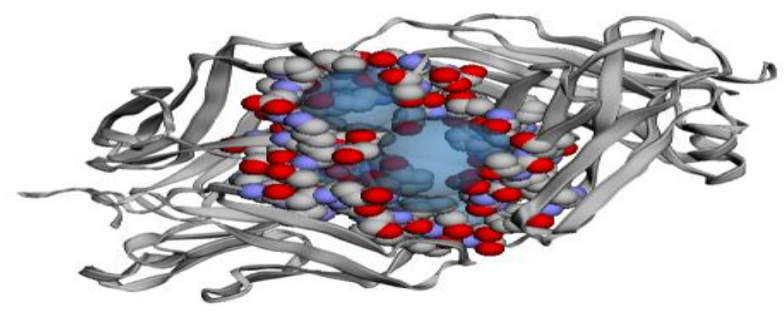

Figure 1: Showing the CAST-p Pocket Binding Sites for AChE and TAU Proteins

Studies on Hydrogen bond interaction of AChE and TAU enzymes through Pymol:

The hydrogen bond interaction of lead compounds was analysed for possible involvement of hydrogen bond formation with amino acid residues on receptor surface.
The results obtained from the hydrogen bond interaction study showed that the marine drug molecules such as ZINC ID 0118 and ZINC ID 0142 possess great AChE and Tau inhibition activity by binding with the active site pockets on target proteins surface.

Table 1: Showing Inter-molecular hydrogen bonding of 1B41 protein through Pymol

\begin{tabular}{|c|c|c|c|c|}
\hline Compound ID & $\begin{array}{l}\text { Protein and ligand } \\
\text { Interactions }\end{array}$ & $\begin{array}{l}\text { Present amino acid } \\
\text { residues }\end{array}$ & Bond angle & Docking score \\
\hline $\begin{array}{l}\text { Compound } 1 \\
\text { ZINC } 0118\end{array}$ & 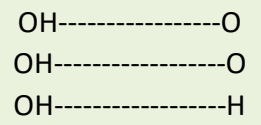 & $\begin{array}{l}\text { TYR-124 } \\
\text { TYR-337 } \\
\text { TYR-133 }\end{array}$ & $\begin{array}{l}3.2 \\
2.9 \\
2.7\end{array}$ & -8.9 \\
\hline $\begin{array}{l}\text { Compound } 2 \\
\text { ZINC } 0040\end{array}$ & $\begin{array}{l}\text { O----------HN } \\
\text { ONF2---------O }\end{array}$ & $\begin{array}{l}\text { PRO-498 } \\
\text { GLN-174 }\end{array}$ & $\begin{array}{l}2.2 \\
3.3\end{array}$ & -8.6 \\
\hline $\begin{array}{l}\text { Compound } 3 \\
\text { ZINC } 0026\end{array}$ & $\begin{array}{l}\text { OE1--------------H } \\
\text { ND2-------------O }\end{array}$ & $\begin{array}{l}\text { GLN-413 } \\
\text { ASN-233 }\end{array}$ & $\begin{array}{l}2.4 \\
2.9\end{array}$ & -8.3 \\
\hline $\begin{array}{l}\text { Compound } 4 \\
\text { ZINC } 0025\end{array}$ & 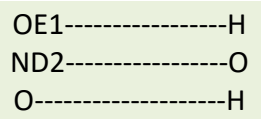 & $\begin{array}{l}\text { GLN-413 } \\
\text { ASN-233 } \\
\text { GLY-234 }\end{array}$ & $\begin{array}{c}2.5 \\
2.9 \\
.6\end{array}$ & -8.3 \\
\hline $\begin{array}{l}\text { Compound } 5 \\
\text { ZINC } 0016\end{array}$ & O----------------H & $\begin{array}{l}\text { GLY-234 } \\
\text { ASN-233 } \\
\text { ASN-233 }\end{array}$ & $\begin{array}{l}2.5 \\
2.5 \\
2.9\end{array}$ & -8.3 \\
\hline $\begin{array}{l}\text { Compound } 6 \\
\text { ZINC } 0115\end{array}$ & 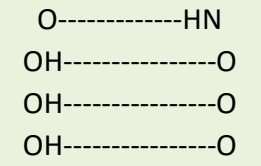 & $\begin{array}{c}\text { TYR-72 } \\
\text { TYR-133 } \\
\text { TYR-133 } \\
\text { TYR-337 }\end{array}$ & $\begin{array}{l}1.8 \\
3.1 \\
2.7 \\
2.8\end{array}$ & -8.2 \\
\hline $\begin{array}{l}\text { Compound } 7 \\
\text { ZINC } 0139\end{array}$ & 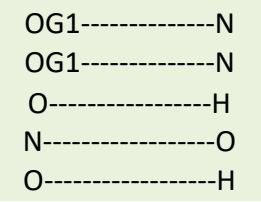 & $\begin{array}{l}\text { THR-238 } \\
\text { THR-238 } \\
\text { PRO-232 } \\
\text { GLU-313 } \\
\text { JRP-532 }\end{array}$ & $\begin{array}{l}3.3 \\
2.5 \\
2.3 \\
3.3 \\
2.7\end{array}$ & -8.0 \\
\hline $\begin{array}{l}\text { Compound } 8 \\
\text { ZINC } 0052\end{array}$ & $\begin{array}{l}\mathrm{NH} 2 \text {-------------O } \\
\mathrm{NH} 2 \text {----------O }\end{array}$ & $\begin{array}{l}\text { ARG-475 } \\
\text { LEU-518 }\end{array}$ & $\begin{array}{l}3.1 \\
2.9\end{array}$ & -8.0 \\
\hline
\end{tabular}


Table 2: Showing Inter-molecular hydrogen bonding of 2V17 protein through Pymol

\begin{tabular}{|c|c|c|c|c|}
\hline Compound ID & $\begin{array}{l}\text { Protein and ligand } \\
\text { Interactions }\end{array}$ & $\begin{array}{l}\text { Present amino acid } \\
\text { residues }\end{array}$ & Bond angle & Docking score \\
\hline $\begin{array}{l}\text { Compound } 1 \\
\text { ZINC } 0142\end{array}$ & $\begin{array}{l}\text { O-------------H } \\
\text { O--------------H }\end{array}$ & $\begin{array}{l}\text { GLN-557 } \\
\text { GLN-557 }\end{array}$ & $\begin{array}{l}2.4 \\
1.9\end{array}$ & -8.3 \\
\hline $\begin{array}{l}\text { Compound } 2 \\
\text { ZINC } 0016\end{array}$ & O--------------O & SER-559 & 3.2 & -8.2 \\
\hline $\begin{array}{l}\text { Compound } 3 \\
\text { ZINC } 0026\end{array}$ & O---------------O & SER-559 & 3.1 & -8.2 \\
\hline $\begin{array}{l}\text { Compound } 4 \\
\text { ZINC } 0040\end{array}$ & $\begin{array}{l}\text { OG-------------O } \\
\text { OG------------H }\end{array}$ & $\begin{array}{l}\text { SER-65 } \\
\text { SER-63 }\end{array}$ & $\begin{array}{l}3.3 \\
3.1\end{array}$ & -7.8 \\
\hline $\begin{array}{l}\text { Compound } 5 \\
\text { ZINC } 0014\end{array}$ & $\begin{array}{l}\text { O-------------N } \\
\text { O----------H }\end{array}$ & $\begin{array}{l}\text { PHE-474 } \\
\text { LEU-495 }\end{array}$ & $\begin{array}{l}2.8 \\
2.7\end{array}$ & -7.6 \\
\hline $\begin{array}{l}\text { Compound } 6 \\
\text { ZINC } 0070\end{array}$ & $\begin{array}{l}\text { OG-------------O } \\
\text { O---------------H } \\
\text { N---------------O } \\
\text { N-------------O }\end{array}$ & $\begin{array}{l}\text { SER-507 } \\
\text { ASP-139 } \\
\text { GLY-136 } \\
\text { CYS-137 }\end{array}$ & $\begin{array}{l}3.1 \\
2.3 \\
2.9 \\
3.4\end{array}$ & -7.6 \\
\hline $\begin{array}{l}\text { Compound } 7 \\
\text { ZINC } 0139\end{array}$ & O-------------H & LEU-495 & 2.5 & -7.5 \\
\hline $\begin{array}{l}\text { COmpound } 8 \\
\text { ZINC } 0145\end{array}$ & $\begin{array}{l}\text { O-------------H } \\
\text { O-----------H }\end{array}$ & $\begin{array}{l}\text { GLN-557 } \\
\text { PHE-474 }\end{array}$ & $\begin{array}{l}2.3 \\
2.0\end{array}$ & -7.5 \\
\hline
\end{tabular}

Protein and Ligand Interaction and Visualization studies through PyMol

After performing docking studies through Auto Dock Vina software, I performed visualization studies by using PyMol software for all selected lead molecules against their enzymes. The results showed the best hydrogen bond interactions and high binding energy values for all following proteins like $1 \mathrm{~B} 41$ and $2 \mathrm{~V} 17$ for their respective lead compounds viz., CID ZINC 0118 (-8.9), and CID ZINC 0142 (-8.3). Further, these molecules showed the best interaction activity on pocket binding site of amino acid residues.
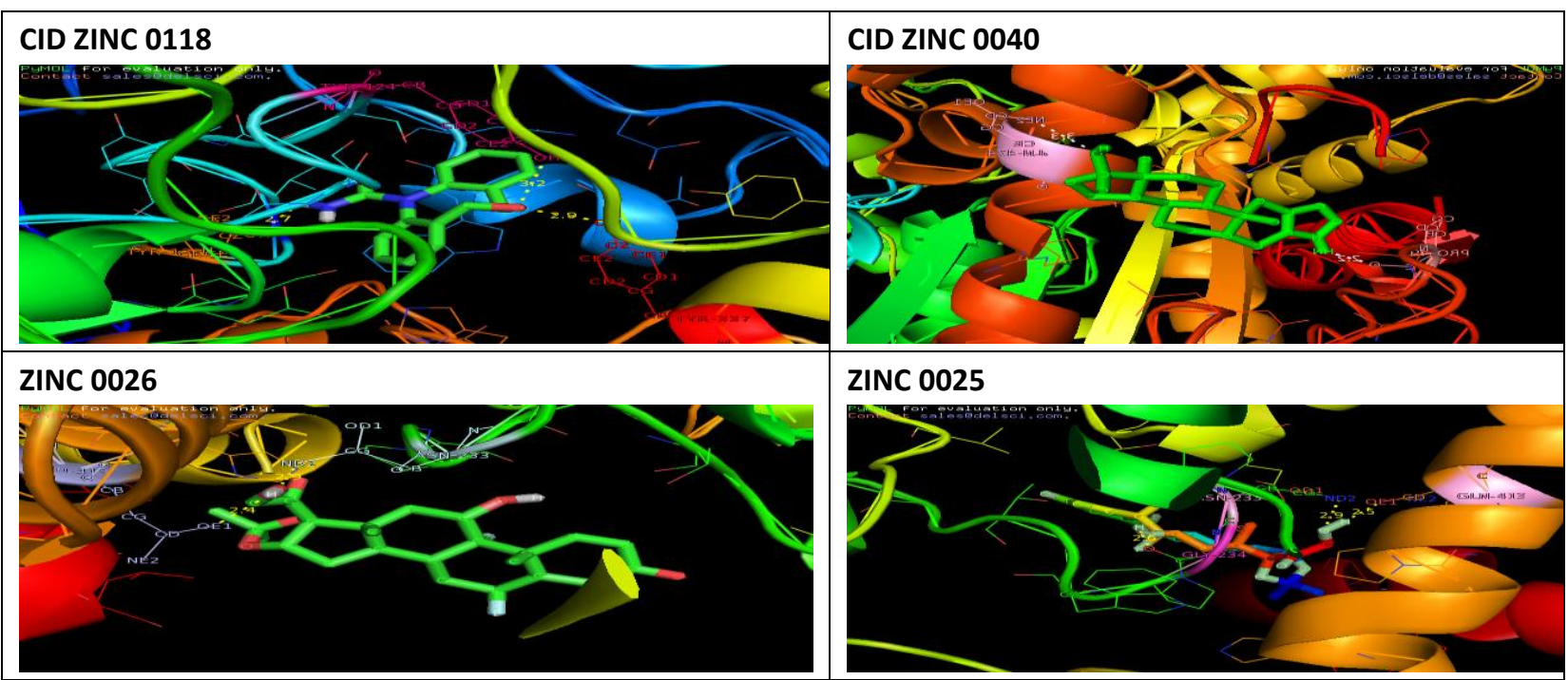

\section{ZINC 0025}
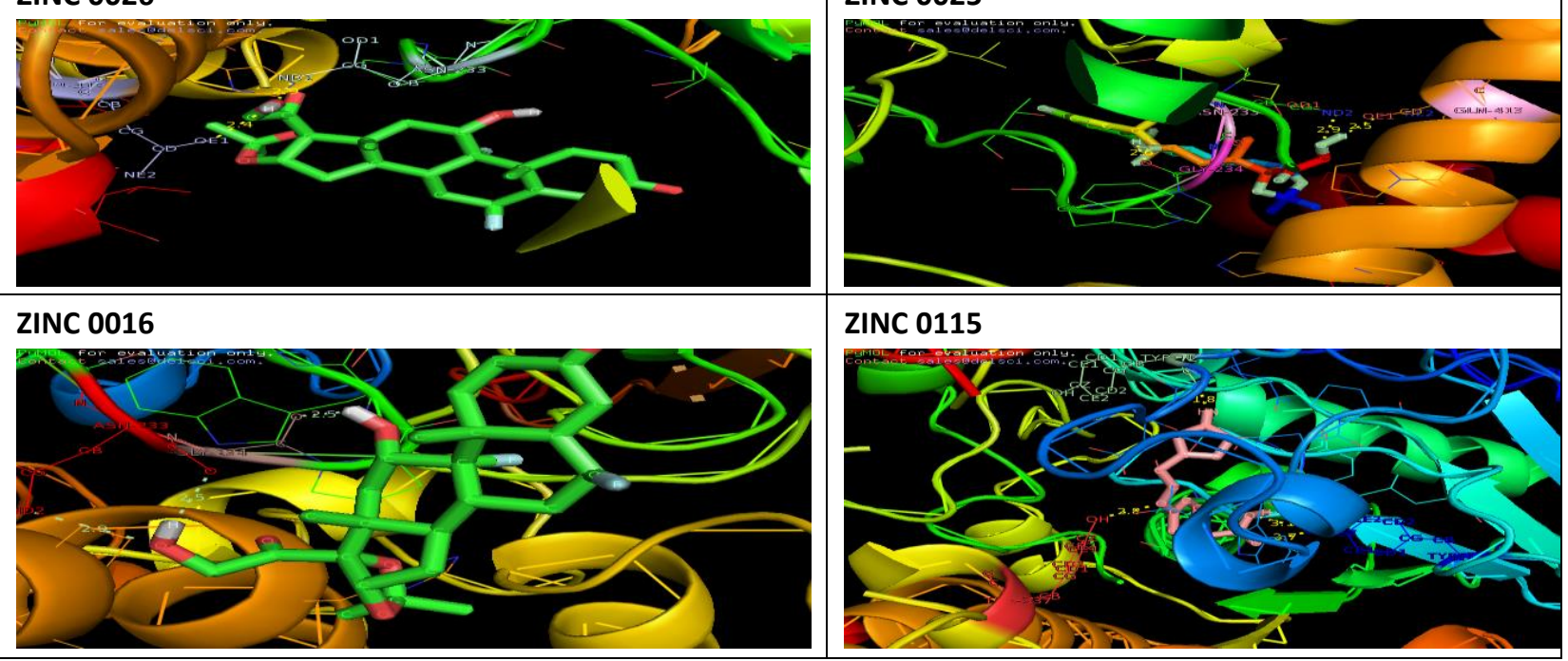


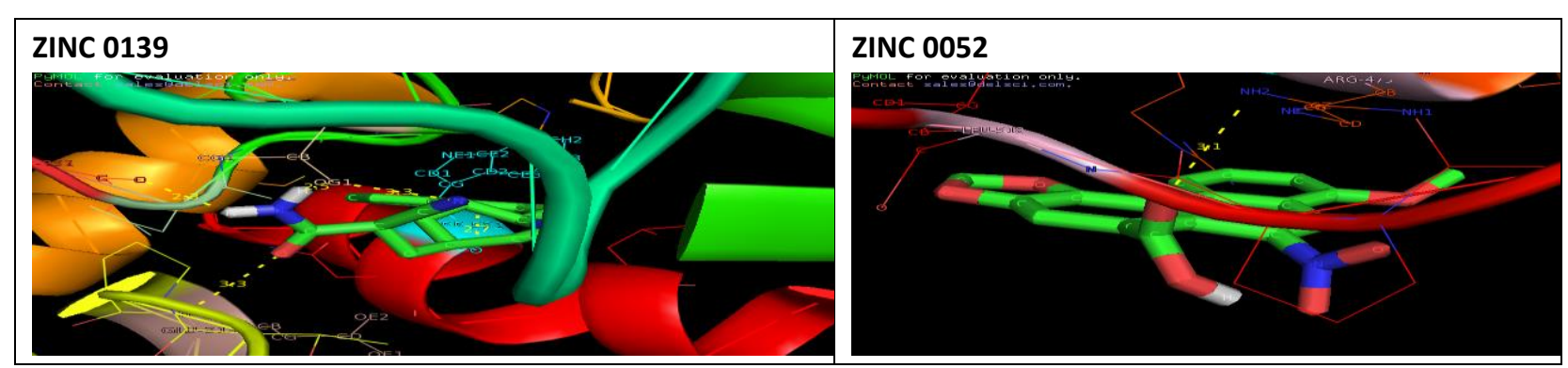

Figure 2: Picture showing the interaction between 1B41 and selected ligand Molecules
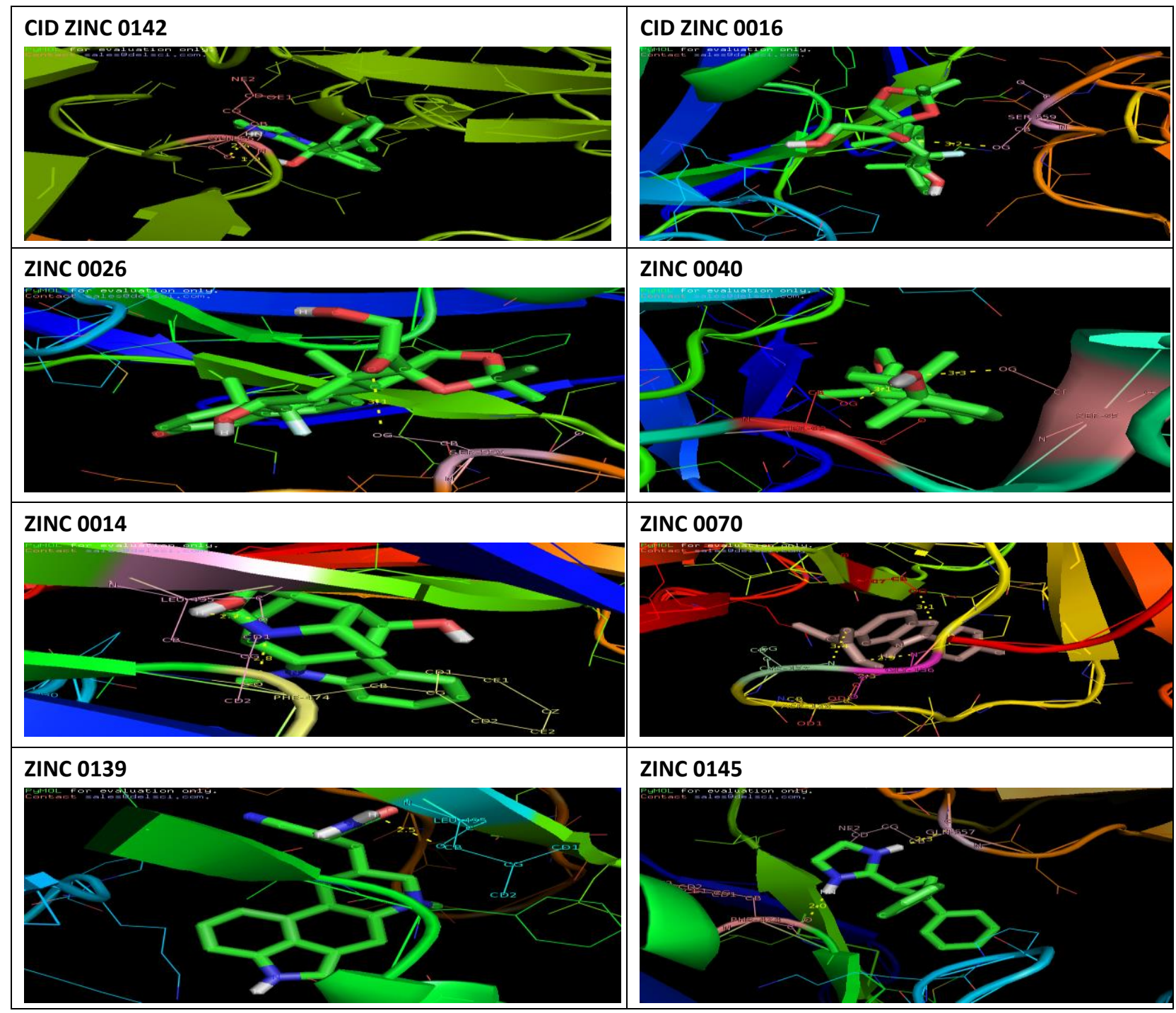

Figure 3: Picture showing the interaction between 2v17 and selected ligand Molecules

Docking results of both enzymes (1B41 \& 2V17) with their inhibitors

The Protein-Ligand interaction plays a significant role in structure-based drug designing. In this research work, Human AChE and Tau proteins receptors were retrieved and docked against marine bioactive compound Squalene. The data Table. 1 and Table. 2 showed different scores such as binding free energy, inhibition constant, intermolecular energy and electrostatic energy values. From this, it was obvious that more number of efficient hydrogen bonding interactions occurred with drug molecules ZINC ID 0118 \& ZINC ID 0142 against AChE and
Tau proteins receptors respectively, when compared to other lead molecules.

Based on our observations, it was predictable that docking calculations through Auto Dock Vina of all lead compounds at their active sites of AChE and Tau proteins were revealed that drug compounds of ZINC ID 0118 \& ZINC ID 0142 were tightly bound with high binding energy principles $-8.9 \&-8.3$ respectively.

\section{Results on prediction of ADME Property analysis}

Further, I studied numerous physically relevant properties of the bioactive compounds from squalene Derivatives, like Molecular weight, $\mathrm{H}$-bond donors, $\mathrm{H}$-bond acceptors

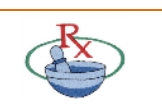


and LogP value according to Lipinski rules performed through Molinspiration tool. They were evaluated through Molinspiration tool and data was presented in Table 4. Based on high binding energy scores, we performed five best lead molecules for ADME property analysis of both receptors. After our investigation, the drug molecules viz. ZINC ID 0118 \& ZINC ID 0142 were found to satisfy the Lipinski properties of five.

\section{Molinspiration}

Molinspiration tool supports internet chemistry community by offering free online services for calculation of important molecular properties like polar surface area, number of hydrogen bond donars, log $\mathrm{P}$, Polar surface area, hydrogen bond acceptors and other properties etc.

Table 3: Data showing Biological Activity Properties for Selected Ligands for 1B41 and 2V17 Enzymes

\begin{tabular}{|c|c|c|c|c|c|c|c|}
\hline Compound ID & $\begin{array}{l}\text { Log } P \\
\text { Value }\end{array}$ & $\begin{array}{c}\text { Molecular } \\
\text { Weight }\end{array}$ & $\begin{array}{l}\text { No. of } \\
\text { atoms }\end{array}$ & $\begin{array}{c}\text { Hydrogen } \\
\text { Bond Donors (nON) }\end{array}$ & $\begin{array}{c}\text { Hydrogen } \\
\text { Bond Acceptors } \\
\text { (nOHNH) }\end{array}$ & $\begin{array}{l}\text { TPSA } \\
\text { Value }\end{array}$ & Volume \\
\hline CID ZINC 0012 & 0.20 & 142.11 & 10 & 4 & 4 & 80.91 & 116.11 \\
\hline CID ZINC 0014 & 3.17 & 352.47 & 25 & 5 & 2 & 91.67 & 354.06 \\
\hline CID ZINC 0016 & 1.49 & 226.32 & 16 & 4 & 2 & 58.20 & 232.58 \\
\hline CID ZINC 0025 & 0.54 & 319.23 & 20 & 2 & 1 & 13.67 & 280.58 \\
\hline CID ZINC 0026 & -3.87 & 269.22 & 19 & 10 & 5 & 157.69 & 213.98 \\
\hline CID ZINC 0040 & -1.95 & 164.16 & 11 & 5 & 4 & 90.15 & 143.76 \\
\hline CID ZINC 0042 & -0.78 & 214.17 & 15 & 6 & 3 & 111.90 & 182.08 \\
\hline CID ZINC 0043 & -1.30 & 148.11 & 10 & 5 & 3 & 94.83 & 125.09 \\
\hline CID ZINC 0052 & -4.00 & 867.66 & 55 & 25 & 11 & 383.88 & 688.70 \\
\hline CID ZINC 0058 & -0.39 & 102.09 & 7 & 3 & 1 & 54.37 & 91.98 \\
\hline CID ZINC 0064 & 0.59 & 181.02 & 10 & 2 & 2 & 40.46 & 133.39 \\
\hline CID ZINC 0070 & 0.38 & 130.14 & 9 & 3 & 1 & 54.37 & 125.37 \\
\hline CID ZINC 0073 & -3.15 & 427.20 & 27 & 15 & 7 & 232.62 & 309.23 \\
\hline CID ZINC 0081 & -4.02 & 288.14 & 18 & 10 & 6 & 181.81 & 220.13 \\
\hline CID ZINC 0115 & -1.08 & 234.28 & 15 & 4 & 1 & 57.61 & 200.60 \\
\hline CID ZINC 0118 & -0.52 & 87.12 & 6 & 2 & 2 & 43.09 & 93.91 \\
\hline CID ZINC 0139 & 5.97 & 420.68 & 30 & 3 & 3 & 60.68 & 445.43 \\
\hline CID ZINC 0142 & 0.15 & 251.25 & 18 & 8 & 4 & 119.32 & 210.27 \\
\hline CID ZINC 0144 & -1.58 & 220.23 & 16 & 5 & 5 & 99.34 & 192.96 \\
\hline CID ZINC 0145 & -3.04 & 192.12 & 13 & 7 & 4 & 132.12 & 152.11 \\
\hline
\end{tabular}

\section{Results showing on PASS prediction tool:}

It is possible with computer program to predict the Activity Spectra for Substances to predict the biological activity spectrum for a compound on the basis of its structural formula Table 4.

Table 4: showing biological activity of lead molecules through PASS Server

\begin{tabular}{|c|c|c|c|}
\hline \multicolumn{4}{|c|}{ Pass prediction results for $1 \mathrm{~B} 41$ receptor ligand CID ZINC 0118: } \\
\hline S. No & Pa value & Pi value & Lead molecule biological activity \\
\hline & 0,378 & 0,066 & Dementia treatment \\
\hline & 0,282 & 0,045 & Vascular dementia treatment \\
\hline & 0,108 & 0,097 & Cholinergic \\
\hline & 0,488 & 0,089 & Acute neurologic disorders treatment \\
\hline & 0,326 & 0,130 & Neuropeptide Y4 antagonist \\
\hline & 0,331 & 0,023 & Dopamine release stimulant \\
\hline & 0,642 & 0,011 & Acetylcholine neuromuscular blocking agent \\
\hline & 0,122 & 0,035 & Acetylcholine nicotinic antagonist \\
\hline & 0,082 & 0,032 & Acetylcholine $\mathrm{M} 3$ receptor agonist \\
\hline
\end{tabular}




\section{B. Pass prediction results of 2V17 receptor ligand CID ZINC 0142}

\begin{tabular}{|l|l|}
\hline 0,219 & 0,085 \\
\hline 0,096 & 0,048 \\
\hline 0,371 & 0,005 \\
\hline 0,291 & 0,022 \\
\hline 0,289 & 0,025 \\
\hline 0,481 & 0,093 \\
\hline 0,363 & 0,164 \\
\hline 0,452 & 0,049 \\
\hline 0,084 & 0,063 \\
\hline 0,046 & 0,039 \\
\hline
\end{tabular}

Dopamine release stimulant

\begin{tabular}{|c|}
\hline Dopamine release stimulant \\
\hline Choline sulfotransferase inhibitor \\
\hline Choline dehydrogenase inhibitor \\
\hline Choline-sulfatase inhibitor \\
\hline Choline kinase inhibitor \\
\hline Acute neurologic disorder treatment \\
\hline Acetylcholine neuromuscular blocking agent \\
\hline Superoxide dismutase inhibitor \\
\hline Neurolysin inhibitor \\
\hline GABA uptake inhibitor \\
\hline
\end{tabular}

\section{DISCUSSION}

The present research study is mainly focused on major two Anti- Alzheimer's agents i.e.1B41 and 2V17 were downloaded from the PDB database. Among all these target proteins, the first enzyme Acetylcholinesterase (1B41) plays a significant role in cholinergic transmission in both the central and peripheral nervous system. Several indications showed that $A C h E$ inhibitors can interface with the progression of Alzheimer's Disease through CAST-P server, which predicts the active pocket binding sites of the selected protein, it was obvious that the following residues were present in their active pocket binding sites 1B41: Tyr124, Tyr-337, Tyr-133, Pro-498, Gln-174, Gln-413, Asn233,Gln-413,Asn-233, Gly-234,Gly-234,Asn-233,Asn233, Tyr-72,Tyr-133, Tyr-133,Tyr-337, Thr-238, Thr-238,Pro232,Glu-313,Trp-532,Arg-475 \& Leu-518 etc. It can also showed best results on PyMol visualization study, it exhibit several hydrogen bonding interactions between Protein and ligands against selected 8 best lead molecules with specific bond angles viz., $\mathrm{OH}------\mathrm{O}\left(3.2 \mathrm{~A}^{0}\right), \mathrm{OH}------\mathrm{O}$ $\left(2.9 A^{0}\right), O H-----H\left(2.7 A^{0}\right)$ showed interaction with ZINC ID 0118, O------HN $\left(2.2 A^{0}\right)$, NE2------O $\left(3.3 A^{0}\right)$ showed interaction with ZINC ID 0040, OE1------H (2.4 $\left.A^{0}\right)$, ND2-----O $\left(2.9 A^{0}\right)$ showed interaction with ZINC ID 0026, OE1-----H $\left(2.5 \mathrm{~A}^{0}\right)$, ND2------O $\left(2.9 \mathrm{~A}^{0}\right)$, O------H $\left(2.6 \mathrm{~A}^{0}\right)$, showed interaction with ZINC ID 0025 and O------H $\left(2.5 \mathrm{~A}^{0}\right)$, O-----$\mathrm{H}\left(2.5 \mathrm{~A}^{0}\right), \mathrm{ND} 2------O\left(2.9 \mathrm{~A}^{0}\right)$ showed interaction with ZINC ID 0016. All these above atoms showed best inhibition activity between protein and ligand molecules with specific bond angles.

The second enzyme structure of the complex of antibody MN423 with a fragment of tau protein (2V17). The tertiary structure dependent monoclonal antibodies are an important tool for investigation of the mechanism of pathological assembly of Intrinsically Disordered Proteins (IDPs). The monoclonal antibody MN423 was raised against the paired helical filaments (PHF) core, the proteolytic cleavage of alzheimers $\mathrm{PHF}$, which retains its characteristic morphological features and consists mainly of tau protein. Through CAST-P server, which predicts the pocket binding site of the selected protein, it was obvious that the following residues were present in the pocket binding site present in protein 2V17: Gln-557, Ser-559, ser-
65, Ser-63, Phe-474, Leu-495, Ser-507, Asp-139, Gly-136, Cys-137, Leu-495, GIn-557, Phe-474 etc. It can also show the Pymol interaction study it exhibit several hydrogen bonding interactions of Protein and ligand atoms presented against selected best 8 lead molecules of different bond angles they are O------H $\left(2.5 \mathrm{~A}^{0}\right)$, O------ $\mathrm{H}$ $\left(1.9 \mathrm{~A}^{0}\right)$ showed interaction with ZINC ID 0142, O------O(3.2 $\left.A^{0}\right)$ showed interaction with ZINC ID 0016, O------O $\left(3.1 A^{0}\right)$ showed interaction with ZINC ID 0026, OG------O $\left(3.3 \mathrm{~A}^{0}\right)$, OG------H $\left(3.1 \mathrm{~A}^{0}\right)$ showed interaction with ZINC ID 0040, O-----N $\left(2.8 \mathrm{~A}^{0}\right)$, O------H $\left(2.7 \mathrm{~A}^{0}\right)$ showed interaction with ZINC ID 0014. All these above atoms showing best inhibition activity against selected protein and ligand molecules with specific bond angles.

\section{CONCLUSION}

From all my studies related to Bioinformatics approach it was observed that the compound squalene showed good binding energy values towards selected enzymes, thus providing an evidence that the lead molecule Squalene can act as Anti-alzheimers compound. However, further investigations are necessary to confirm the biological activity through in-depth studies develop potential compounds for prevention and treatment of Alzheimers Disease.

Acknowledgement: We thank the Co-ordinator, DBTsupported BIF Centre for providing the networking facilities to execute this research work.

\section{REFERENCES}

1. Mustazza C, Borioni A, Rosaria Del Giudice M, Gatta F, Ferretti R, Synthesis and cholinesterase activity of phenylcarbamates related to Rivastigmine, a therapeutic agent for Alzheimer's disease, Eur. J. Med. Chem. 2002; 37: 91-109.

2. Maczurek A, Hager $K$, Kenklies $M$, Sharman $M$, Martins $R$, Engel J, Lipoic acid as an anti-inflammatory and neuroprotective treatment for Alzheimer's disease, Adv. Drug. Del. Rev. 2008; 60: 1463-1470.

3. Scarpini E, Scheltens P, Feldman H, Treatment of Alzheimer's disease: current status and new perspectives, Lancet. Neurol. 2003; 2: 539-547.

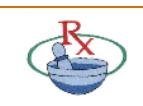


4. Ucar G, Gokhan N, Yesilada A, Bilgin AA, 1-N-Substituted thiocarbamoyl-3- phenyl-5-thienyl-2-pyrazolines: A novel cholinesterase and selective monoamine oxidase B inhibitors for the treatment of Parkinson's and Alzheimer's diseases, Neurosci. Lett. 2005; 382: 327-331.

5. Vitorovic-Todorovic MD, Juranic IO, Mandic LM, Drakulic BJ, 4-Aryl-4-oxo-Nphenyl-2-aminylbutyramides as acetyl- and butyrylcholinesterase inhibitors, Preparation, anticholinesterase activity, docking study, and 3D structureactivity relationship based on molecular interaction fields, Bio.org. Med. Chem. 2010; 18: 1181-1193.

6. Araujo JQ, Araujo de Brito M, Boas Hoelz LV, de Alencastro RB, Castro HC, Rodrigues C, et al: Receptor-dependent (RD) 3D-QSAR approach of a series of benzyl piperidine inhibitors of human acetylcholinesteras (HuAChE). Eur.J. Med. Chem. 2011, 46:39-51.

7. Benzi G \& Moretti A, Neurobiol. Aging. 1995; 16: 661-674.

8. Inestrosa NC, Alvare A and Garrido J. In Alzheimer's Disease: Biology, Diagnosis and Therapeutics. John Wiley and Sons. London, 1997; 500-510.

9. Rajendran L, Schneider A, Schlechtingen G, Weidlich S, Ries J, Braxmeier T, Schwille P, Schulz J.B, Schroeder C, Simons M, Jennings G, Knolker H.J, Simon, K. Efficient inhibition of the Alzheimer's disease $\beta$-secretase by membrane targeting, Science. 2008; 25: 520-523.

10. Kadam S.U, Tiwari B.K, ODonnell, C.P. Application of novel extraction technologies for bioactives from marine algae, J. Agric. Food. Chem. 2013; 61: 4667-4675.

11. Smit, A.J, Medicinal and pharmaceutical uses of seaweed natural products, A. review. J. Appl. Phycol. 2004; 16: 245262.
12. Andrade P.B, Barbosa M, Matos, R.P, Lopes G, Vinholes J, Mouga T, Valentão $P$, Valuable compounds in macro algae extracts, Food Chem. 2013, 138: 1819-1828.

13. Cho S, Kim S-K, Neuro pharmacological properties of marine plants, In Marine Pharmacognosy: Trends and Applications, Taylor \& Francis. Boca Raton, FL, USA, 2012; pp. 355-372.

14. Sugimoto $H$, Yamanishi $Y$, limura $Y$, Kawakami $Y$, Donepezil Hydrochloride (E2020) and Other Acetylcholinesterase Inhibitors, Curr. Med. Chem. 2000; 7: 303-339.

15. Berman HM, john w, Zukang F, Gary G, Bhat TN, Helge W, Ilya NS and Philip EB, The protein Data Bank, Nucleic Acids research. 2000; 28 (1): 235-242.

16. http://Pubchem.ncbi.nlm.nih.gov/search/search.cgi.

17. Dudas J, Ouyang Z, Tseng J, Binkowski A, Turpaz Y, \& Linang J, Nucleic acids Res. 2006; 34: W116-118.

18. ArgusLab 4.0 Mark A: Thompson Planaria Software LLC. Seattle, WA. http://www.arguslab.com.

19. Clara Grosso 1, Patrícia Valentão 1, Federico Ferreres 2 and Paula B. Andrade 1, Bioactive Marine Drugs and Marine Biomaterials for Brain Diseases, Mar. Drugs. (ISSN16603397) 2014; 12: 2539-2589, doi:10.3390/md12052539

20. Bikadi $Z$ and Hazai E, Application of the PM6 semi-empirical method to modelling proteins enhances docking accuracy of Auto Dock, J. Cheminf. 2009; 1: 15.

21. Halgren TA, Merck molecular force field. I. Basis, form, scope, parametrization, and performance of MMFF94, Journal of Computational Chemistry. 1998; 17 (5): 490-519.

22. McGaughey GB, Sheridan RP, Bayly $\mathrm{Cl}$, Culberson JC, Kreatsoulas C, Comparison of topological, shape, and docking methods in virtual screening, J. ChemInf. Model. 2007; 47: 1504-1519.

Source of Support: The author(s) received no financial support for the research, authorship, and/or publication of this article.

Conflict of Interest: The author(s) declared no potential conflicts of interest with respect to the research, authorship, and/or publication of this article.

For any question relates to this article, please reach us at: editor@globalresearchonline.net

New manuscripts for publication can be submitted at: submit@globalresearchonline.net and submit_ijpsrr@rediffmail.com 